\title{
Are tropical reptiles really declining? A six-year survey of snakes in a tropical coastal rainforest: role of prey and environment
}

\author{
José Pablo Barquero-González ${ }^{1 *}$, Tracie L. Stice ${ }^{1}$, Gianfranco Gómez ${ }^{1}$ \& Julián Monge-Nájera ${ }^{2}$ \\ 1. Laboratorio de Sistemática, Genética y Evolución (LabSGE), Escuela de Ciencias Biológicas, Universidad Nacional, \\ Heredia, Costa Rica; jopbgon@gmail.com, https://orcid.org/0000-0001-8343-6050, drakebaycostarica@gmail.com, \\ https://orcid.org/0000-0001-7207-1690, gianfranco.gomez@gmail.com, https://orcid.org/0000-0002-9301-2136 \\ 2. Laboratorio de Ecología Urbana, Vicerrectoría de Investigación, Universidad Estatal a Distancia (UNED), 2050 San \\ José, Costa Rica; julianmonge@gmail.com, https://orcid.org/0000-0001-7764-2966 \\ * Correspondence
}

Received 05-VIII-2019. Corrected 06-II-2020. Accepted 07-II-2020.

\begin{abstract}
Introduction: Even though snake declines seem to be a reality in many parts of the world, some reports are based on anecdotal evidence and there is a need of prolonged and intensive studies, especially in the tropics, for corroboration. Objective: To investigate if snake populations in Drake Bay are decreasing, and if there is a relationship with prey, time, temperature, rain and moonlight. Methods: We counted snakes seen per hour when walking along a single trail in the coastal forest of Drake Bay, Costa Rica. We walked the trail at night for a total of 842 nights (over 4000 hours of observations), from 2012 through 2017 and recorded all the individual snakes we could see with head flashlights. We used ANOVA tests to check correlations among counts per hour with moonlight and rain; and graphic analysis for associations with diet, temperature, month and year. Results: We recorded 25 species (five families); which feed mostly on terrestrial vertebrates. Counts per hour have fallen over the years, especially for species that prey on amphibians and reptiles; Mastigodryas melanolomus has remained in similar numbers; and Siphlophis compressus has not been seen since May 2016. Temperature is relatively constant along the year in Drake, but month strongly affected the counts, which increased from August to September. Most species were seen more often in rainy nights $(0.11$ per hour versus only 0.03 per hour in nights without rain, ANOVA $\mathrm{P}<0.05$ ); we saw less Leptodeira septentrionalis on bright nights $(0.12$ per hour, versus 0.21 per hour in dark nights; ANOVA, $\mathrm{P}=0.01)$, but all other species were unaffected by moonlight (ANOVA, P > 0.05). Conclusion: Night field counts of snakes in Drake Bay, Costa Rica, are not strongly affected by light or temperature, but are lower when there is no rain and show a strong decline from 2012 through 2017, particularly for species that feed on amphibians and reptiles. We have no reason to believe that the decline is an erroneous interpretation or that the snakes moved elsewhere, the decline of snakes in Drake seems to be real and needs attention from the conservation authorities.
\end{abstract}

Key words: snake demography, climate change, Drake Bay, reptile population, trópico.

Barquero-González, J.P., Stice, T.L., Gómez, G., \& Monge-Nájera, J. (2020). Are tropical reptiles really declining? A six-year survey of snakes in a tropical coastal rainforest: role of prey and environment. Revista de Biología Tropical, 68(1), 336-343.

On the one hand, snakes are good ecological indicators because they reflect prey fluctuations (Moore et al., 2003; Madsen, Ujvari, Shine, \& Olsson, 2006) and thanks to their long life span, late sexual maturity, low reproductive frequency, site fidelity and significant mortality early in life (Scott \& Seigel, 1992; Shetty \& Shine, 2002). On the other hand, assessments of snake populations are difficult because of their cryptic lifestyle and sporadic activity (Gibbons et al., 2000); but despite methodological difficulties, in the last 45 years there 
have been population decline reports from temperate regions, and more recently, from tropical regions. Outside the tropics, the reports include Europe (Reading et al., 2010) and the United States of America (Mount, 1975; Rudolph \& Burgdorf, 1997; Conant \& Collins, 1998; Hallam, Wheaton, \& Fischer, 1998; Tuberville, Bodie, Jensen, LaClaire, \& Gibbons, 2000; Winne, Willson, Todd, Andrews, \& Gibbons, 2007). Accounts from warmer regions include the extinction of the Round Island Burrowing Boa, endemic to Mauritius (Bullock, 1986; Greene, 2000), and population decreases of snakes in Nigeria (Reading et al., 2010) and parts of Australia (Lukoschek, Beger, Ceccarelli, Richards, \& Pratchett, 2013; Lukoschek, 2018).

Even though snake declines seem to be a reality in many parts of the world, some reports are based on anecdotal evidence (Krysko, 2001; Böhm et al., 2013; Urban, 2015); prolonged and intensive studies are recommended to detect actual declines (Kery, 2002; Sewell, Guillera-Arroita, Griffiths, \& Beebee, 2012; Hileman et al., 2018), but such studies are rare, especially in the tropics (Böhm et al., 2013; Urban, 2015).

Here we compare nighttime snake sightings with prey, rain, moonlight and temperature; along a six year period, in an intensively sampled tropical coastal rainforest trail.

\section{MATERIALS AND METHODS}

We counted snakes seen per hour while walking at night along a trail (our "transect"), repeatedly over a six year period (2012-2017), in lowland tropical rainforest, $12-38 \mathrm{~m}$ above sea level, near the Agujas River (Location and trail map in Fig. 1, Digital Appendix 1); the site is in Drake Bay, South Pacific of Costa Rica (N 08.69420 - 08.69490 \& W 083.67421 083.67495). All counts and data recording were made by Stice and Gómez as part of their work as field guides, while accompanied by small groups of tourists, who did not participate directly in the study. Except when necessary to corroborate identification, we did not touch the animals.

Snake counts: We walked the trail at night for a total of 842 nights (over 4000 hours of field observations), using head flashlights to count all the snakes that we could see along the transect without disturbing the vegetation to look for them; identified species in situ using the guides by Savage (2002) and Solórzano (2004); and photographed them for taxonomic corroboration (representative photographs for all species seen are presented in Digital Appendix 2). We worked mostly from 1930 to 2200 hours, but a few counts started at 1730 and ended at 2245 hours (full details of sampling hours and dates are presented in Digital Appendix 2).

Snake diet: Prey type preference was taken from Savage (2002) and Solórzano (2004); categories are not mutually exclusive, and full details are presented in Table 1 .

Annual and monthly data for rain and temperature: Rain and temperature data were kindly provided by the Instituto Meteorológico Nacional de Costa Rica from the nearest meteorological station at Rancho Quemado, partially covering the period 2012-2017. The institute reported that no rain records were available from January 2012 to July 2012, December 2016 to March 2017 and September 2017 to December 2017. No temperature records were available from January 2012 to July 2012 and from September 2017 to December 2017, so these periods were not included when calculating the mean monthly values that appear in Fig. 5 (Digital Appendix 1).

Note: Rancho Quemado, where the meteorological station is located, has an altitude of $240 \mathrm{~m}$ above sea level while the survey site in Drake Bay has an altitude of 12 to $38 \mathrm{~m}$, so we expected a difference in temperature between the study site and the meteorological station. To assess this difference, we made temperature measurements directly in Drake Bay for seven months, from February 2017 to August 2017, 
and compared them with Rancho Quemado for that same time period. We found that average temperatures in Drake Bay are 2 to $3{ }^{\circ} \mathrm{C}$ higher than temperatures in Rancho Quemado, but that the trends along the timeline are the same. We did not have the funds to do this comparison in other years, but have no reason to doubt that the difference existed along the six years because lower sites are warmer that higher sites in a predictable value (Salter, Hobbs, Wheeler, Kostbade, \& Trenton, 2005).

Rain: We used both official rain records by Instituto Meteorológico Nacional de Costa Rica (i.e. government data), and our own classification of rain condition during fieldwork as "No Rain", "Light Rain" and "Heavy Rain", to make a double assessment of possible correlations with snake counts. We applied ANOVA tests for our classification and visual inspection for the government data (Full details in Fig. 5, and in Table 1 and Table 2, Digital Appendix 1).

Moonlight: Instead of using published moonlight data, which might not apply under the forest cover (cloudy skies produce dark nights even when the moon is full), we recorded moonlight conditions on every trip directly in the trail; we classified nights as "Dark" (practically no moonlight); "Bright" (good moonlight allowing us to follow the trail easily) and "Semibright" (intermediate between Dark and Bright).

Statistical analyses: In the case of rain and moonlight, we analyzed "Snakes seen per hour" independently for each of the most common species, and pooled data for the rare species into a single category called "Others" so that counts were enough for ANOVA tests (Table 1 and Table 2 in Digital Appendix 1). We used visual inspection for comparisons among months and among years (full details and graphs in Digital Appendix 1, Fig. 2, Fig. 3, Fig. 4, Fig. 5, Fig. 6 and Fig. 7). Raw data sets are available on Zenodo (DOI: 10.5281/ zenodo.3531953).

\section{RESULTS}

Species observed: We recorded a total of 25 snake species along the six years (Table 1), representing five families: Boidae, Colubridae, Dipsadidae, Elapidae, and Viperidae.

Effect of prey: Most species at Drake feed on terrestrial vertebrates (Table 1) and, over the years, the number of species with each prey type remained relatively constant (Fig. 2 in Digital Appendix 1). However, the numbers of individuals seen per hour fell continuously, from 2012 through 2017, for snake species that feed on amphibians and reptiles (Fig. 3 in Digital Appendix 1).

Annual patterns: Our analysis (Fig. 4 in Digital Appendix 1) indicates that, despite wide oscillations in the number of animals seen per hour, in recent years, encounters with Leptodeira septentrionalis, Imantodes cenchoa and Enuliophis sclateri are less common, $M$. melanolomus has remained in similar numbers; and Siphlophis compressus has not been seen after April 2016.

Monthly pattern: Visual inspection of Fig. 5 (Digital Appendix 1) shows a monthly pattern marked by a stable temperature $(\mathrm{H}=$ $59.80, \mathrm{P}=0.5)$, rain falling mostly from February through October $(\mathrm{H}=70.07, \mathrm{P}=0.5)$, and snake counts increasing from August to September $(\mathrm{H}=2.14, \mathrm{P}=0.5)$.

Effect of rain: Statistical data for rain appear in detail in Table 1 and Fig. 6 (Digital Appendix 1). Encounters per hour with $I$. cenchoa were not affected by rain (ANOVA P $>0.05$ ), but $L$. septentrionalis was seen more often in nights without rain $(0.20$ per hour, versus only 0.12 per hour in rainy nights; ANOVA $\mathrm{P}<0.05$ ). All the other species (pooled) had the opposite pattern: they were found more often in rainy nights $(0,11$ per hour versus only 0,03 per hour in nights without rain, ANOVA $\mathrm{P}<0.05$ ). The same applies to the abundant E. sclateri: 
TABLE 1

Cumulative checklist of snake species found on the surveyed years and their main prey items according to the literature (Savage, 2002; Solórzano, 2004)

\begin{tabular}{lcccccc}
\multicolumn{1}{c}{ Species } & \multicolumn{2}{c}{ Prey item } & & & \\
Boa imperator & Invertebrates & Fish & Amphibians & Reptiles & Birds & Mammals \\
Bothriechis schlegelii & - & - & - & $\mathrm{X}$ & $\mathrm{X}$ & $\mathrm{X}$ \\
Bothrops asper & - & - & $\mathrm{X}$ & $\mathrm{X}$ & $\mathrm{X}$ & $\mathrm{X}$ \\
Chironius flavopictus & - & - & $\mathrm{X}$ & $\mathrm{X}$ & $\mathrm{X}$ & $\mathrm{X}$ \\
Clelia clelia & - & - & $\mathrm{X}$ & - & - & - \\
Coniophanes fissidens & - & - & - & $\mathrm{X}$ & $\mathrm{X}$ & $\mathrm{X}$ \\
Corallus ruschenbergerii & - & - & $\mathrm{X}$ & $\mathrm{X}$ & & - \\
Dendrophidion percarinatum & - & - & - & $\mathrm{X}$ & $\mathrm{X}$ & $\mathrm{X}$ \\
Enuliophis sclateri & - & - & $\mathrm{X}$ & - & - & - \\
Hydrophis platurus & - & - & - & $\mathrm{X}$ & - & - \\
Imantodes cenchoa & - & $\mathrm{X}$ & - & - & - & - \\
Leptodeira septentrionalis & - & - & $\mathrm{X}$ & $\mathrm{X}$ & - & - \\
Leptophis ahaetulla & - & - & $\mathrm{X}$ & $\mathrm{X}$ & - & - \\
Leptophis nebulosus & - & - & $\mathrm{X}$ & $\mathrm{X}$ & $\mathrm{X}$ & - \\
Mastigodryas melanolomus & - & - & $\mathrm{X}$ & - & - & - \\
Micrurus alleni & - & - & $\mathrm{X}$ & $\mathrm{X}$ & $\mathrm{X}$ & $\mathrm{X}$ \\
Ninia maculata & - & - & $\mathrm{X}$ & $\mathrm{X}$ & - & - \\
Oxyrhopus petolarius & $\mathrm{X}$ & - & - & - & - & - \\
Phrynonax poecilonotus & - & - & $\mathrm{X}$ & $\mathrm{X}$ & - & $\mathrm{X}$ \\
Trimetopon barbouri? & - & - & - & - & $\mathrm{X}$ & $\mathrm{X}$ \\
Sibon nebulatus & - & - & $\mathrm{X}$ & $\mathrm{X}$ & - & - \\
Siphlophis compressus & $\mathrm{X}$ & - & - & - & - & - \\
Spilotes pullatus & - & - & - & $\mathrm{X}$ & - & - \\
Stenorrhina degenhardtii & - & - & - & $\mathrm{X}$ & $\mathrm{X}$ & $\mathrm{X}$ \\
Tantilla supracincta & $\mathrm{X}$ & - & - & - & - & - \\
\hline & $\mathrm{X}$ & - & - & - & - & - \\
\hline
\end{tabular}

0.04 per hour in rainy nights versus only 0.01 with no rain (ANOVA $\mathrm{P}<0.0003$ ).

Effect of moonlight: We saw less L. septentrionalis on bright nights $(0.12$ per hour, versus 0.21 per hour in dark nights; ANOVA, $\mathrm{P}=0.01$ ), but all other species were unaffected (ANOVA, $\mathrm{P}>0.05$; Table 2 and Fig. 7 in Digital Appendix 1).

\section{DISCUSSION}

We found that most of the studied snakes, feed primarily on terrestrial vertebrates, and were less seen as the years passed, this was especially true for amphibians and reptiles predators. This could be related with the reduction in the availability of some, but not of all, of their prey species, because some frogs, for example, remained abundant throughout the study period (Gianfranco Gómez, personal observation). Specialist snakes are highly vulnerable to prey decline because they are less likely to exploit alternative resources in response to shifting environmental conditions (Terborgh \& Winter, 1980; Gaston, 1994), and, according to Webb and Shine (1998), snakes that ambush prey are particularly susceptible because of their low rate of food acquisition.

The stable temperature of this rainforest along the year, experiences most of its climatic variation due to rain falling, mainly from February through October. Snake counts increasing 
at the end of the rainy season, matches previous studies with tropical species. Basically, the rainy season allows the reproduction of amphibians, and their increased activity attracts the snakes that prey on them (Duellman, 1958; Shine \& Madsen, 1996; Daltry, Ross, Thorpe, \& Wüster, 1998; Luiselli \& Akani, 2002; Oliveira \& Martins, 2001; Morrison \& Bolger, 2002). There are, however, reports of a different pattern, i.e., of no correlation between counts of Neotropical snakes and rainfall (Henderson \& Hoevers, 1977; Martins, 1994; Bernarde \& Abe, 2006), which only match our findings for I. cenchoa, and future researchers could evaluate if its arboreal behavior can explain its "independence" from rain. In our study, the fewer sightings of $L$. septentrionalis on nights with strong moonlight could be a behavior to avoid predation, like that of Crotalus viridis in Colorado (see Clarke, Chopko, \& Mackessy, 1996), but it was the exception, we saw with the same frequency all the other species at Drake both in dark and illuminated nights. This is unusual, as many snakes increase their activity in full moon, when prey are more visible (Lillywhite \& Brischoux, 2012; Connolly \& Orrock, 2018), like the tropical tree snake Boiga irregularis that searches for forest spots where moonlight is stronger (Campbell, Mackessy, \& Clarke, 2008).

Like any study, this study has limitations, and the main one is the impossibility of detecting all the snakes in the forest. Another one is the fact that a reduction in the number of species seen along the trail does not mean that the snakes are dying, it has to be taken into account that maybe they just moved from the area for a variety of reasons that could include microclimatic variation and the search of prey elsewhere. We do not think the presence of humans could cause this, as the number of people walking the transect every night is low and it is limited to a brief period of the night. Despite changes in the leaf litter can have a large impact on invertebrates, and in turn this affects amphibians and reptiles that are part of the litter food web (Henderson, Dixon, \& Soini, 1978; Martins, 1994), we did not notice differences in leaf litter during the study period (see Fig. 3, Digital Appendix 2).

Small environmental fluctuations can also affect the visibility of snakes (Seigel, Collins, \& Novak, 1987; Zamora-Camacho, MorenoRueda, \& Pleguezuelos, 2010; Rugiero, Milana, Petrozzi, Capula, \& Luiselli, 2013), and of course there is a possibility that snakes hide, or leave the trail altogether. However, we have no reason to believe that our ability to see the snakes has decreased over the years, and a few species remained constant in our counts along the study. We also do not think they moved to less disturbed habitat because of human alteration of habitats around the reserve as some species have reappeared in subsequent years. We believe that the decline of snakes in Drake is real and needs attention from the conservation authorities.

Ethical statement: authors declare that they all agree with this publication and made significant contributions; that there is no conflict of interest of any kind; and that we followed all pertinent ethical and legal procedures and requirements. All financial sources are fully and clearly stated in the acknowledgements section. A signed document has been filed in the journal archives.

\section{ACKNOWLEDGMENTS}

We thank Carolina Seas for her assistance with data analysis, Sergio Aguilar for his help in the elaboration of the images, Alejandro Solórzano, Héctor Zumbado, Mahmood Sasa and several anonymous reviewers for excellent recommendations to improve the manuscript, and Instituto Meteorológico Nacional for providing climatic data free of charge. This study was financed by the authors. 


\section{RESUMEN}

“¿Están desapareciendo los reptiles tropicales? Seis años de monitoreo de las serpientes en un bosque tropical costero: el papel de las presas y el ambiente". Introducción: A pesar de que la disminución de serpientes parece ser una realidad en muchas partes del mundo, algunos informes se basan en evidencia anecdótica y existe la necesidad de estudios prolongados e intensivos, especialmente en los trópicos, para corroborar. Objetivo: Investigar si las poblaciones de serpientes en Bahía Drake están disminuyendo y si existe una relación con la presa, el tiempo, la temperatura, la lluvia y la luz de la luna. Metodología: Contamos las serpientes que se ven por hora al caminar por un sendero en el bosque costero de la Bahía Drake, Costa Rica. Recorrimos el sendero por la noche durante un total de 842 noches (más de 4000 horas de observaciones), desde el 2012 hasta el 2017, y registramos todas las serpientes individuales que pudimos ver con linternas de cabeza. Utilizamos pruebas ANDEVA para verificar correlaciones entre conteos por hora con luz de luna y lluvia; y análisis gráfico para asociaciones con dieta, temperatura, mes y año. Resultados: Registramos 25 especies (cinco familias); se alimentan principalmente de vertebrados terrestres. Las cuentas por hora han disminuido a lo largo de los años, especialmente para especies que se alimentan de anfibios y reptiles; Mastigodryas melanolomus se ha mantenido en números similares; y Siphlophis compressus no se ha visto desde mayo de 2016. La temperatura es relativamente constante durante todo el año en Drake, pero el mes afectó fuertemente los conteos, que aumentaron de agosto a septiembre. La mayoría de las especies se observaron con mayor frecuencia en noches lluviosas $(0.11$ por hora versus solo 0.03 por hora en noches sin lluvia, ANDEVA P < 0.05); vimos menos Leptodeira septentrionalis en noches brillantes $(0.12$ por hora, frente a 0.21 por hora en noches oscuras; ANDEVA, $\mathrm{P}=0.01$ ), pero todas las demás especies no se vieron afectadas por la luz de la luna (ANDEVA, P > 0.05). Conclusión: El recuento nocturno de serpientes en la Bahía de Drake, Costa Rica, no se ve muy afectado por la luz o la temperatura, pero es más bajo cuando no llueve y muestra un fuerte descenso desde 2012 hasta 2017, particularmente para las especies que se alimentan de anfibios y reptiles. No tenemos ninguna razón para creer que la disminución sea una interpretación errónea o que las serpientes se mudaron a otra parte, la disminución de las serpientes en Drake parece ser real y necesita la atención de las autoridades de conservación.

Palabras clave: demografía de serpientes, cambio climático, Bahía Drake, población de reptiles, trópico.

\section{REFERENCES}

Bernarde, P.S., \& Abe, A.S. (2006). A snake community at Espigão do Oeste, Rondônia, southwestern Amazon, Brazil. South American
Journal of Herpetology, 1(2),102-113. DOI: 10.2994/1808-9798(2006)1[102:ASCAED]2.0.CO;2

Böhm, M., Collen, B., Baillie, J.E., Bowles, P., Chanson, J., Cox, N., \& Rhodin. A.G. (2013). The conservation status of the world's reptiles. Biological Conservation, 157, 372-385. DOI: 10.1016/j. biocon.2012.07.015

Bullock, D.J. (1986). The ecology and conservation of reptiles on Round Island and Gunner's Quion, Mauritius. Biological Conservation, 37(2), 135-156. DOI: 10.1016/0006-3207(86)90088-1

Campbell, S.R., Mackessy, S.P., \& Clarke, J.A. (2008). Microhabitat use by brown tree snakes (Boiga irregularis): effects of moonlight and prey. Journal of Herpetology, 42(2), 246-250. DOI: 10.1655/07-054.1

Clarke, J.A., Chopko, J.T., \& Mackessy, S.P. (1996). The effect of moonlight on activity patterns of adult and juvenile prairie rattlesnakes (Crotalus viridis viridis). Journal of Herpetology, 30(2), 192-197. DOI: $10.2307 / 1565509$

Conant, R., \& Collins, J.T. (1998). Reptiles and Amphibians of North America ( $4^{\text {th }}$ Ed.). New York, USA: Houghton Mifflin.

Connolly, B.M., \& Orrock, J.L. (2018). Habitat-specific capture timing of deer mice (Peromyscus maniculatus) suggests that predators structure temporal activity of prey. Ethology, 124(2),105-112. DOI: 10.1111/ eth. 12708

Daltry, J.C., Ross, T., Thorpe, R.S., \& Wüster, W. (1998). Evidence that humidity influences snake activity patterns: a field study of the Malayan pit viper Calloselasma rhodostoma. Ecography, 21(1), 25-34. DOI: 10.1111/j.1600-0587.1998.tb00391.x

Duellman, W.E. (1958). A monographic study of the colubrid snake genus Leptodeira. Bulletin of the American Museum of Natural History, 114, article 1.

Gaston, K.J. (1994). What is rarity? In K.J. Gaston (Ed.). Rarity (pp. 1-21). Dordrecht, Netherlands: Springer. DOI: $10.1007 / 978-94-011-0701-3$ 1

Gibbons, J.W., Scott, D.E., Ryan, T.J., Buhlmann, K.A., Tuberville, T.D., Metts, B.S., ... Winne, C.T. (2000). The Global Decline of Reptiles, Déjà Vu Amphibians. BioScience, 50(8), 653-666. DOI: 10.2307/1445695

Greene, H.W. (2000). Snakes: the evolution of mystery in nature. Los Angeles, CA, USA.: University of California Press.

Hallam, C.O., Wheaton, K., \& Fischer R.A. (1998). Species Profile: Eastern Indigo Snake (Drymarchon corals couperi) on Military Installations in the Southeastern United States (Technical Report, No. WES-TR-SERDP-98-2) Army Engineer Waterways 
Experiment Station Vicksburg, MS, USA. DOI: 10.21236/ADA342329

Henderson, R.W., Dixon, J.R., \& Soini, P. (1978). On the seasonal incidence of tropical snakes. Wisconsin, USA: Milwaukee Public Museum.

Henderson, R.W., \& Hoevers, L.G. (1977). The seasonal incidence of snakes at a locality in northern Belize. Copeia, 1977, 349-355. DOI: 10.2307/1443914

Hileman, E.T., Allender, M.C., Bradke, D.R, Faust, L.J., Moore, J.A., Ravesi, M.J., \& Tetzlaff, S.J. (2018). Estimation of Ophidiomyces prevalence to evaluate snake fungal disease risk. The Journal of Wildlife Management, 82(1), 173-181. DOI: 10.1002/ jwmg. 21345

Kery, M. (2002). Inferring the absence of a species: a case study of snakes. The Journal of Wildlife Management, 66(2), 330-338. DOI: 10.2307/3803165

Krysko, K.L. (2001). Ecology, conservation, and morphological and molecular systematics of the kingsnake, Lampropeltis getula (Serpentes: Colubridae) (Ph.D Dissertation). University of Florida, Florida, USA.

Lillywhite, H.B., \& Brischoux, F. (2012). Is it better in the moonlight? Nocturnal activity of insular cottonmouth snakes increases with lunar light levels. Journal of Zoology, 286(3), 194-199. DOI: 10.1111/j.1469-7998.2011.00866.x

Luiselli, L., \& Akani, G.C. (2002). Is thermoregulation really unimportant for tropical reptiles? Comparative study of four sympatric snake species from Africa. Acta Oecologica, 23(2), 59-68. DOI: 10.1016/ S1146-609X(02)01134-7

Lukoschek, V. (2018). Population declines, genetic bottlenecks and potential hybridization in sea snakes on Australia's Timor Sea reefs. Biological Conservation, 225, 66-79. DOI: 10.1016/j.biocon.2018.06.018

Lukoschek, V., Beger, M., Ceccarelli, D., Richards, Z., \& Pratchett, M. (2013). Enigmatic declines of Australia's sea snakes from a biodiversity hotspot. Biological Conservation, 166, 191-202. DOI: 10.1016/j.biocon.2013.07.004

Madsen, T., Ujvari, B., Shine, R., \& Olsson, M. (2006). Rain, rats and pythons: Climate-driven population dynamics of predators and prey in tropical Australia. Austral Ecology, 31(1), 30-37. DOI: 10.1111/j.1442-9993.2006.01540.x

Martins, M. (1994). História natural e ecologia de uma taxocenose de serpentes de mata na região de Manaus, Amazônia Central, Brasil. Campinas, SP (Ph.D Dissertation). Universidade Estadual de Campinas, Brasil.

Moore, J.L., Balmford, A., Brooks, T., Burgess, N.D., Hansen, L.A., Rahbek, C., \& Williams, P.H. (2003).
Performance of sub-Saharan vertebrates as indicator groups for identifying priority areas for conservation. Conservation Biology, 17(1), 207-218. DOI: 10.1046/j.1523-1739.2003.01126.x

Morrison, S.A., \& Bolger, D.T. (2002). Variation in a sparrow's reproductive success with rainfall: food and predator-mediated processes. Oecologia, 133(3), 315-324. DOI: 10.1007/s00442-002-1040-3

Mount, R.H. (1975). The Reptiles and Amphibians of Alabama. Auburn (AL), USA: Auburn University, Alabama Agricultural Experimental Station.

Oliveira, M.E., \& Martins, M. (2001). When and where to find a pitviper: activity patterns and habitat use of the lancehead, Bothrops atrox, in central Amazonia, Brazil. Herpetological Natural History, 8(2), 101-110.

Reading, C.J., Luiselli, L.M., Akani, G.C., Bonnet, X., Amori, G., Ballouard, J.M., ... Rugiero, L. (2010). Are snake populations in widespread decline? Biology Letters, 6(6), 777-780. DOI: 10.1098/rsbl.2010.0373

Rudolph, D.C., \& Burgdorf, S.J. (1997). Timber rattlesnakes and Louisiana pine snakes of the west Gulf Coastal Plain: hypotheses of decline. Texas Journal of Science, 49(3), 111-122.

Rugiero, L., Milana G., Petrozzi, F., Capula, M., \& Luiselli, L. (2013). Climate-change-related shifts in annual phenology of a temperate snake during the last 20 years. Acta Oecologica, 51, 42-48. DOI: 10.1016/j. actao.2013.05.005

Salter, C., Hobbs, J., Wheeler, J., Kostbade, J., \& Trenton, J. (2005). Essentials of World Regional Geography ( $2^{\text {nd }}$ Ed.). New York, USA: Harcourt Brace.

Savage, J.M. (2002). The amphibians and reptiles of Costa Rica: a herpetofauna between two continents, between two seas. Chicago, Illinois, USA: University of Chicago.

Scott, N.J.Jr., \& Seigel, R.A. (1992). The management of amphibians and reptile populations: Specific priorities and methodological and theoretical constraints. In D.R. McCullough, \& R.H. Barrett (Eds.), Wildlife 2001: Populations (pp. 343-368). London, England: Elsevier Applied Science. DOI: 10.1007/978-94-011-2868-1 29

Seigel, R.A., Collins, J.T., \& Novak, S.S. (1987). Snakes: ecology and evolutionary biology. New York, USA: MacMillan Publishing Company. DOI: 10.2307/1445695

Sewell, D., Guillera-Arroita, G., Griffiths, R.A., \& Beebee, T.J. (2012). When is a species declining? Optimizing survey effort to detect population changes in reptiles. PloS one, 7(8), e43387. DOI: 10.1371/journal. pone. 0043387 
Shetty, S., \& Shine, R. (2002). Philopatry and homing behavior of sea snakes (Laticauda colubrina) from two adjacent islands in Fiji. Conservation Biology, 16(5), 1422-1426. DOI: 10.1046/j.1523-1739.2002.00515.x

Shine, R., \& Madsen, T. (1996). Is thermoregulation unimportant for most reptiles? An example using water pythons (Liasis fuscus) in tropical Australia. Physiological Zoology, 69(2), 252-269. DOI: 10.1086/ physzool.69.2.30164182

Solórzano, A. (2004). Serpientes de Costa Rica: distribución, taxonomía e historia natural. San José, Costa Rica: Editorial INBio.

Terborgh, J., \& Winter, B. (1980). Some causes of extinction. Conservation Biology, 2, 119-133.

Tuberville, T.D., Bodie, J.R., Jensen, J.B., LaClaire, L., \& Gibbons, J.W. (2000). Apparent decline of the southern hog-nosed snake, Heterodon simus. Journal of the Elisha Mitchell Scientific Society, 116(1), $19-40$.
Urban, M.C. (2015). Accelerating extinction risk from climate change. Science, 348(6234), 571-573. DOI: 10.1126/science.aaa4984

Webb, J.K., \& Shine, R. (1998). Ecological characteristics of a threatened snake species, Hoplocephalus bungaroides (Serpentes, Elapidae). Animal Conservation, 1(3), 185-193. DOI: 10.1111/j.1469-1795.1998. tb00028.x

Winne, C.T., Wilson, J.D., Todd, B.D., Andrews, K.M., \& Gibbons, J.W. (2007). Enigmatic decline of a protected population of Eastern Kingsnakes, Lampropeltis getula, in South Carolina. Copeia, 2007(3), 507-519. DOI: 10.1643/0045-8511(2007)2007[507:EDOAPP ]2.0.CO;2

Zamora-Camacho, F.J., Moreno-Rueda, G., \& Pleguezuelos, J.M. (2010). Long-and short-term impact of temperature on snake detection in the wild: further evidence from the snake Hemorrhois hippocrepis. Acta Herpetológica, 5(2), 143-150. 